\title{
Engineering Studies
}

Volume 4, Issue 3, 2012

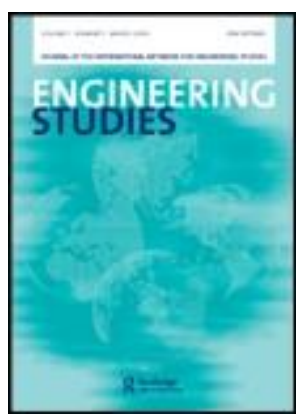

Going public: The first Portuguese National Engineering Meeting and the popularization of the image of the engineer as an artisan of progress (Portugal, 1931)

DOI:10.1080/19378629.2012.709519

Maria Paula Diogo \& Ana Cardoso de Matos

pages $185-204$

Received: 07 Nov 2010

Accepted: 03 Mar 2012

Version of record first published: 27 Jul 2012

\begin{abstract}
In this paper, we explore the use of the Portuguese generalist press as a tool to convey to the lay public the image of the engineer as the main artisan of progress and of the modern twentieth century society. In 1931, Portuguese engineers met for the first time in a national congress. Besides the obvious intention of asserting their professional identity, the first National Engineering Meeting, explicitly aimed at publicizing the work of Portuguese engineers as key players in the progress and wealth of the country, thus regaining their space as protagonists in the 'new Portugal'. We argue that Portuguese engineers organized their first National Meeting as a way of lobbying the new Ditadura Nacional (National Dictatorship) government. They felt that they had lost power as decision-makers during the republican period (1910-1926) and they wanted to show the new leaders that they were the vital force in the building of a 'new Portugal.' Their strategy was to show their professional success and potential, both in a formal and academic milieu (papers presented at the conference) and in an informal technodazzling atmosphere (the exhibition) directed toward the general public.
\end{abstract}

